\title{
PERBANDINGAN METODE DEPTH OF FIELD PADA LENSA KAMERA FOTOGRAFI DENGAN EFEK LENSA PADA SOFTWARE ANIMASI
}

\author{
Ahmad Faisal Choiril Anam Fathoni ${ }^{1}$; Dermawan Syamsuddin ${ }^{2}$ \\ Jurusan Desain Komunikasi Visual, School of Design, BINUS University \\ Jln. K.H. Syahdan No. 9, Palmerah, Jakarta Barat 11480 \\ 19anam.fathoni@gmail.com; 2dsyamsuddin@binus.edu
}

\begin{abstract}
The knowledge of photography becomes fundamental importance in the understanding of digital cinematography. The work of a good photography is a blend of knowledge and photographic ability (skill) correctly. By learning photography properly, it allows an animator or digital art workers to apply some standard cinematography as well. By knowing the comparison between photography with "photographic" in 3D animation, animators will be easier to create a digital aesthetic standard with the help of the software. This paper discusses the comparison of the use of photographic camera lenses and camera parameters found in animation software 3D Studio Max. The final form is the camera pictures and parameters of used lens with the results of rendering images with the software-related parameter.
\end{abstract}

Keywords: photography, depth of field, camera lenses, software animation

\begin{abstract}
ABSTRAK
Pengetahuan fotografi menjadi dasar yang penting dalam pemahaman sinematografi digital. Hasil karya fotografi yang bagus merupakan perpaduan keilmuan dan kemampuan (skill) memotret yang benar. Dengan belajar fotografi secara benar, hal itu memudahkan seorang animator atau pekerja seni digital menerapkan satu standar sinematografi yang baik pula. Dengan mengetahui perbandingan antara fotografi dengan "fotografis" dalam animasi 3D, animator akan lebih mudah membuat standar estetika secara digital dengan bantuan software. Pada penulisan ini akan dibahas perbandingan pemakaian lensa kamera fotografi dengan penggunaan kamera dan parameter yang terdapat pada software animasi 3D Studio Max. Bentuk akhirnya berupa gambar-gambar hasil foto dan parameter pemakaian lensa dengan gambar-gambar hasil rendering dengan parameter sebuah software terkait.
\end{abstract}

Kata kunci: fotografi,depth of field, lensa kamera, software animasi 


\section{PENDAHULUAN}

Salah satu kesamaan penilaian antara karya fotografi dengan karya animasi adalah prinsipprinsip estetika gambar. Estetika yang dimaksud adalah nilai keindahan maupun kelayakan untuk dilihat audiensinya. Kesamaan tersebut tampil pada objek sebagai esensi pesan visual yang bisa dilihat langsung mata penonton. Misalnya sebuah foto yang menampilkan gambar sebuah rumah tua dengan latar belakang gunung, maka visualisasi tersebut dengan mudah juga bisa dilakukan di ranah animasi. Perbedaannya adalah dalam proses perekaman gambar. Jika fotografi gambar memang direkam langsung dengan kamera, dalam animasi gambar tersebut memang harus dibentuk atau digambar artis visualnya dulu. Dalam animasi 3D, gambar sejenis harus didesain atau dibentuk oleh animator sebagai model dahulu dengan bantuan software tertentu.

Untuk menghasilkan gambar-gambar yang indah diperlukan metode maupun cara tertentu yang membantu mengarahkan para animator tersebut. Cara tertentu ini menjadi penting, sebab dalam pembuatan animasi terdapat beberapa faktor signifikan yang memengaruhi hasil akhir animasinya.

Adanya kesamaan nilai estetika gambar dan gaya fotografis pada karya animasi 3D membuat pengetahuan tentang fotografi menjadi penting. Menjadi penting karena ternyata prinsip-prinsip fotografi pun diterapkan pada proses "pengambilan” gambar pada software animasi 3D. Dengan demikian, jika seseorang mempunyai pengetahuan fotografi yang baik, fundamental pengetahuannya akan sangat berguna ketika bekerja pada bidang animasi 3D.

Faktor pengetahuan teknis mengoperasikan dan memahami fungsi dasar kerja kamera dan lensa fotografi membantu seorang animator memindahkan kaidah tersebut dalam ranah software. Yang menjadi pertanyaan adalah bagaimana pemahaman fotografi khususnya aspek fungsi lensa harus dipindahkan ke ranah animasi 3D agar hasil kualitas estetikanya mendekati realitas fotografi.

\section{METODE PENELITIAN}

Penelitian dilakukan dengan melakukan kajian terhadap proses tentang bagian kamera dan fungsinya, cara pengambilan dalam fotografi, kemudian parameter penggunaan lensa dan pengaturan sudut pandang fotografis yang dipindahkan ke parameternya di software animasi. Perbandingan dilakukan dengan contoh-contoh gambar yang jelas dan parameter yang pasti.

\section{HASIL DAN PEMBAHASAN}

\section{Fotografi dan Sinematografi}

Fotografi mempunyai pengertian proses merekam pantulan cahaya yang mengenai benda. Pada awal sejarahnya, media penyimpan gambar yang terbentuk berupa lembaran atau pita yang berisi emulsi kimia yang disebut pita film. Pada masa modern sekarang ini, fungsi pita seluloid diganti oleh sebuah sensor yang sering disebut sensor CCD atau sensor CMOS. Pada bidang sensor yang menerima refleksi citra gambar tersebut yang kelak menjadi gambar yang direkam ke media digital seperti $S D$ card atau Compact Flash.

Animasi dalam pengertiannya merupakan bentuk citra visual yang bersifat sekuensial dan mempunyai muatan pesan atau informasi berbentuk cerita tertentu. Dalam pembuatannya, animasi 
membutuhkan metode sinematografi tertentu. Sementara sinematografi sendiri sangat terkait dengan teknis fotografi. Sinematografi sebagai bidang keilmuan, pembahasannya mencakup tentang teknik menangkap gambar dan menggabung-gabungkan gambar tersebut sehingga menjadi rangkaian gambar yang dapat menyampaikan ide ataupun pesan tertentu. Perbedaannya, peralatan fotografi menangkap gambar tunggal, sedangkan sinematografi menangkap rangkaian gambar. Jadi, sinematografi adalah gabungan antara fotografi dengan teknik perangkaian gambar. Dalam sejarahnya sinematografi sangat dekat dengan film dalam pengertian sebagai media penyimpan maupun sebagai genre seni. Film yang berwujud pita seluloid berfungsi sebagai media penyimpan emulsi atau zat yang peka cahaya. Benda inilah yang selalu digunakan sebagai media penyimpan di awal pertumbuhan sinematografi. Dalam sejarahnya, pengetahuan sinematografi memiliki beberapa aspek yang menjadi cakupannya, yaitu: aspek kamera dan lensa, lighting, warna, grain emulsi film, komposisi, staging \& blocking. Pada pembahasan kali ini hanya mengkhususkan pada perbandingan aspek pemakaian lensa dengan implementasi di software.

\section{Software Animasi}

Perkembangan teknologi memudahkan animator membuat karya yang lebih mudah dan hasil yang menakjubkan yang sebelumnya sulit dilakukan. Pada pembuatan film animasi klasik, rangkaian gambar dihasilkan dari gambar yang dibuat satu persatu, di mana tim kerjanya sangat banyak. Mereka membuat "gambar antara" (in between) yang jumlahnya bisa mencapai ribuan gambar. Perkembangan komputer dan perangkat lunaknya membuat proses yang sangat berbeda. Walaupun tidak menggantikan sepenuhnya peran artis animasi klasik, peran komputer pada kenyataan banyak diakui telah mengambil peran para pembuat "gambar antara" tersebut. Proses perekaman gambar inilah yang disebut rendering. Artinya komputer membuat kalkulasi gambar dan menggambar satu-satu dengan detil yang mengagumkan.

Pada bahasan berikut, program yang menjadi pembanding adalah 3D Studio Max. Software ini merupakan program grafik berbasis vektor 3 dimensi untuk pembuatan animasi dan pemodelan 3 dimensi. Perangkat lunak ini dikembangkan oleh Autodesk Media \& Entertainment. Kasus yang diangkat terletak pada penerapan depth of field dari pemakaian lensa kamera fotografi dengan aplikasi software 3D.

\section{Pemakaian lensa fotografi untuk efek depth of field}

Gambar berikut merupakan lensa dengan bukaan terbesar f/1.4. Diafragma atau aperture (atau sering disebut bukaan) berfungsi untuk mengatur jumlah volume cahaya yang masuk. Penulisan angka diafragma biasanya adalah $\mathrm{f} / 2, \mathrm{f} / 2.8, \mathrm{f} / 4, \mathrm{f} / 5.6, \mathrm{f} / 8, \mathrm{f} / 11$, dan f/16, dan seterusnya.

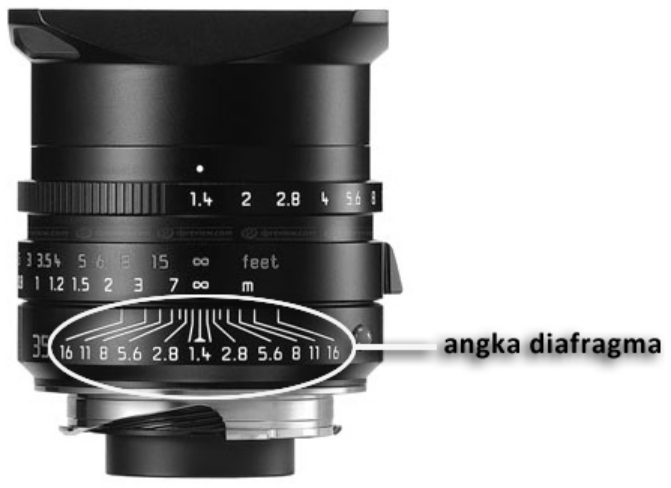

Gambar 1 Lensa dengan angka diafragma untuk menghasilkan depth of field pada kamera fotografi 
Bukaan besar, bukaan diafragma yang besar digunakan untuk menghasilkan foto dengan subjek yang tajam dengan latar belakang blur. Bukaan kecil, bukaan kecil akan menghasilkan gambar yang tajam mulai dari foreground hingga background. Bukaan kecil biasanya digunakan dalam pemotretan pemandangan alam yang memang membutuhkan ketajaman di seluruh bagian foto.

Depth of field adalah ruang tajam atau focus yang terbentuk antara subjek terdekat dengan yang terjauh dalam bentuk ketajaman gambar. Depth of field sangat tergantung pada: (1) diafragma, semakin kecil diafragma, semakin besar depth of field yang dihasilkan; (2) jarak fokus lensa (focal length). Semakin panjang focal length, semakin sempit depth of field. Pada lensa sudut lebar/wide angle, memiliki depth of field yang sangat besar. Fungsinya adalah untuk mengaburkan latar belakang dengan tujuan menonjolkan obyek utama.

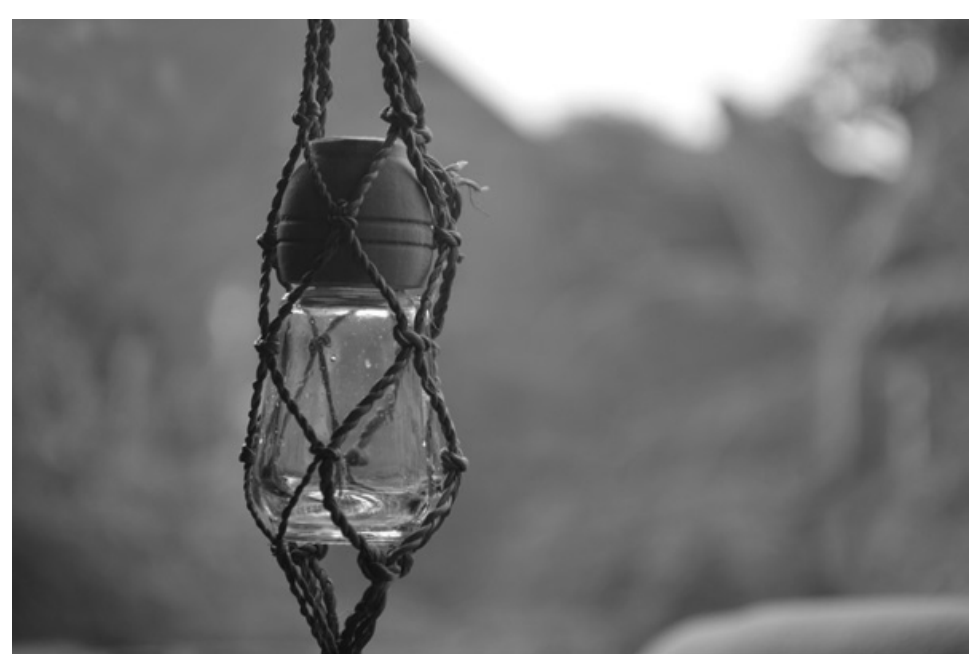

Gambar 2 Hasil pemotretan dengan lensa bukaan besar 3.5 untuk menghasilkan depth of field

\section{Penerapan pada Software 3D S Max}

Berikut penerapan depth of field di software. Perhatikan parameter angka berbeda dengan angka pada diafragma lensa kamera fotografi.

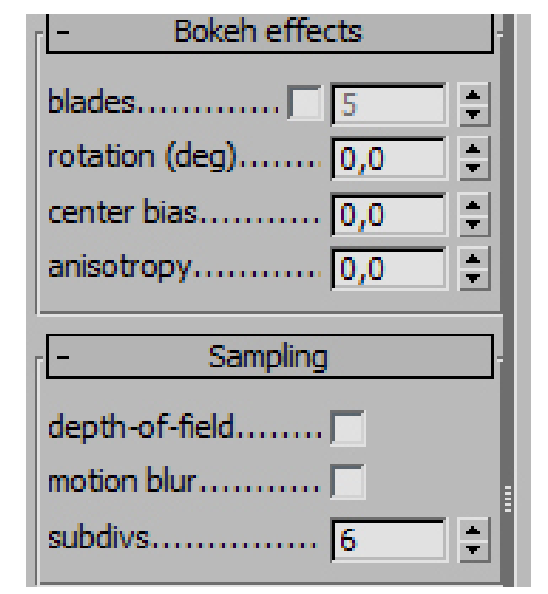

Gambar 3 Screen shot menu depth of field di 3ds max 


\section{Z Depth Images}

Selain itu, kesan kedalaman bisa dicapai dengan metode $\mathrm{Z}$ depth image. Gambar di bawah merupakan hasil rendering software. Konsep image yang dihasilkan adalah menampilkan citra yang serealistis mungkin dengan pendekatan efek lensa yang menghasilkan fokus pada area tertentu. Jika kita memotret dengan kamera konvensional untuk benda dengan yang sama, kita tinggal menyediakan obyek sejenis, mengatur lampu, dan mengatur parameter pada kamera dan lensa, maka hasil akan langsung terlihat. Metodenya yaitu rendering channel untuk menghasilkan $\mathrm{Z}$ depth layer.

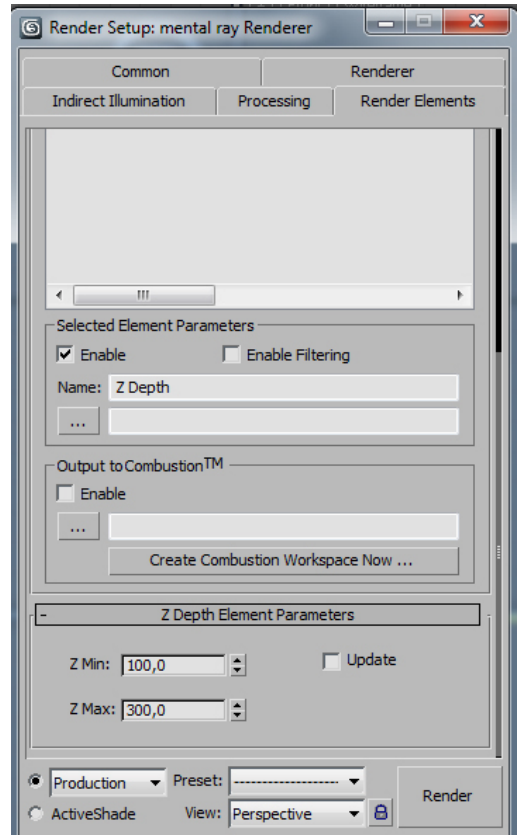

Gambar 4 Screen shot menu Rendering Channel untuk menghasilkan $\mathrm{Z}$ depth Layer

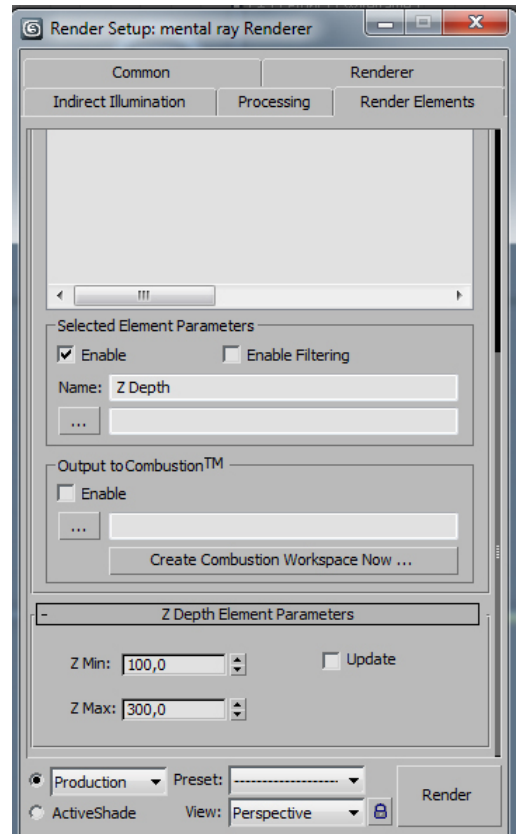

Gambar 5 Hasil pemotretan dengan lensa bukaan besar 3.5 untuk menghasilkan menghasilkan depth of field

Untuk menghasilkan kesan kedalaman ini, diperlukan layer-layer yang memberikan informasi kedalaman ruang dengan pola intensitas yang menggunakan pola greyscale (Z-depth). Dengan demikian, hasil akhirnya akan menyerupai depth of field pada gambar yang direkam kamera fotografi.

Berikut ini adalah gambar yang dihasilkan dengan rendering standar atau original $3 D$ rendering. Walaupun tampak realistis, kesan kedalaman tidak ada. Berbeda jika kita memakai teknik fotografi yang "memainkan" angka diafragma untuk menciptakan depth of field.

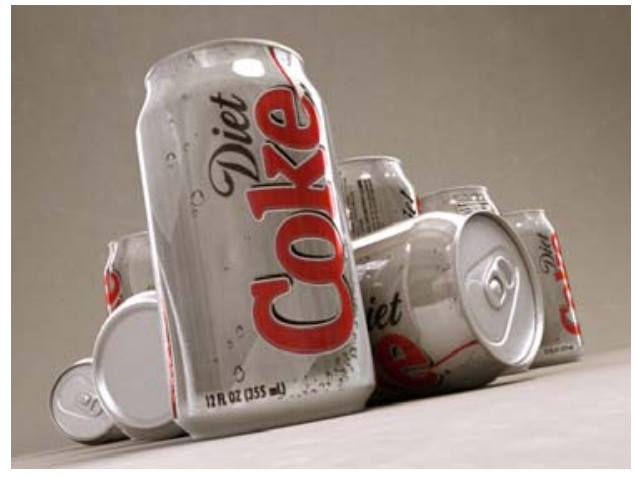

Gambar 6 Image yang dihasilkan dengan rendering standar atau original 3D rendering

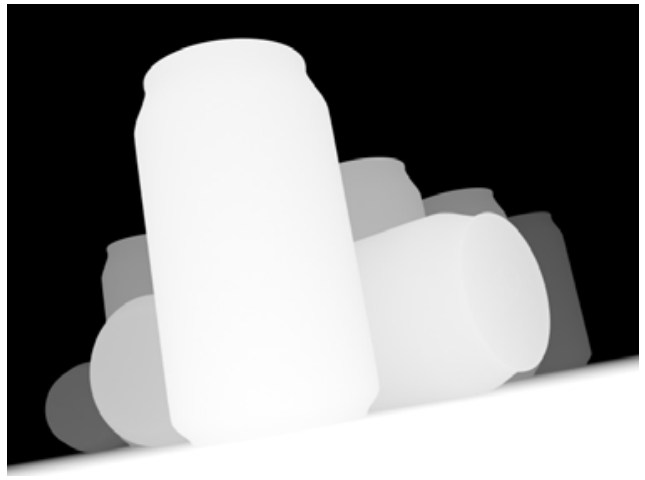

Gambar 6 Hasil render Gambar channel Z depth 
Kombinasi Z Depth yang memanfaatkan layer-layer grayscale dalam proses 3D renderingnya memberikan hasil yang lebih realistik fotografi. Hal ini tampak pada gambar berikut.

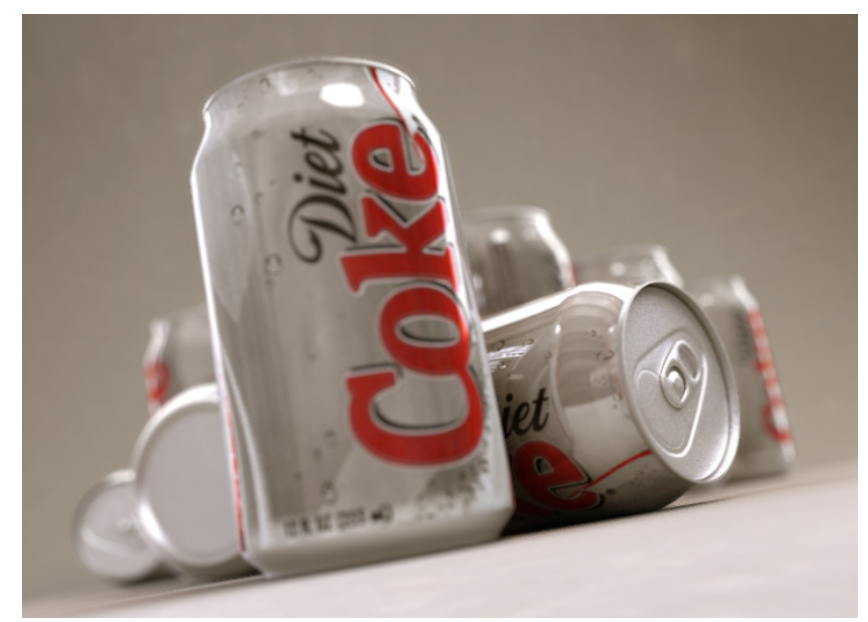

Gambar 7 Hasil render Combination Zdepth dan 3D rendering

\section{SIMPULAN}

Pada perbandingan ini, peranan pemahaman tentang lensa menjadi tolak ukur yang memengaruhi penerapan di software animasi 3D. Citra yang se-realistis (photorealistic) mungkin dengan pendekatan "efek" lensa mampu menghasilkan fokus pada objek yang menjadi perhatian utama. Fotografi konvensional hasilnya dipengaruhi lensa dan parameter bukaan diafragma. Kedalaman ruang tajam pada 3D software memerlukan layer atau lapisan tertentu yang memberikan informasi kedalaman ruang. Pada akhirnya, kesan kedalaman ruang tajam bisa dicapai juga dengan memanfaatkan pengetahuan fotografi dalam pemakaian software 3D animasi.

\section{DAFTAR PUSTAKA}

Ablan, D. (2002). (Digital) cinematography \& directing. Indianapolis: New Riders.

Ayers, R. (1995). Guide to video production. Australian Film, Televison \& Radio School.

Hirsch, R. (2008). Light and lens: Photography in the digital age. Burlington: Focal Press.

Smith, G. H. (2006). Camera lenses: From box camera to digital. Washinton: SPIE.

White, H. (1994). How to produce effective TV comercials. Lincolnwood (Chicago): NTC Bussines Book. 